\title{
The role of Langmuir circulation in suspension freezing
}

\author{
Edward W. KEMPEMA, ${ }^{1}$ Dirk DETHLEFF ${ }^{2}$ \\ ${ }^{1}$ Department of Geology and Geophysics, PO Box 3006, University of Wyoming, Laramie, WY 82071-3006, USA \\ E-mail: kempema@uwyo.edu \\ ${ }^{2}$ Institute for Polar Ecology, University of Kiel, Wischhofstrasse 1-3, D-24148 Kiel, Germany
}

\begin{abstract}
In November 2004 we used an acoustic Doppler velocimeter (ADV) to measure the three components of velocity in Langmuir circulation (LC) cells when frazil was forming in a lake. LC circulation was indicated by windrows of slush ice on the water surface. We also collected samples of lake water, ice interstitial water and ice to determine their sediment concentrations. The ADV record showed rotating currents in the cross-wind/vertical plane indicative of LC. Downward-directed velocities were large enough to entrain frazil into the water column for $27 \%$ of the $97 \mathrm{~min}$ observation time at the ADV location. Sediment concentrations in the ice and interstitial water samples were greater than concentrations in water-column samples collected in upwelling zones of LC cells. We conclude that suspension freezing was forming particle-laden ice as frazil trapped below LC convergence zones grew in downwelled, supercooled water. The rotating roll vortices of Langmuir circulation play an important role in forming sediment-laden ice.
\end{abstract}

\section{INTRODUCTION}

Sediment-laden or 'turbid' sea ice is common over much of the Arctic Ocean (Barnes and others, 1982; Osterkamp and Gosink, 1984; Reimnitz and Kempema, 1988; Kempema and others, 1989; Reimnitz and others, 1993; Nürnberg and others, 1994; Dethleff and others, 1998; Eicken and others, 2005). Although the distribution of sediment in ice can take many forms, it usually consists of silt- and clay-sized particles distributed through the upper layers of the ice cover. Depending on the process of ice formation, sediment can be uniformly distributed throughout the upper layer of the ice or the ice sheet can have a stratigraphy of interbedded clean and dirty layers (Eicken and others, 2005). Sediment-laden sea ice forms over all Arctic continental shelves to a greater or lesser degree. Sediment entrainment into ice is important because it affects sediment, pollutant and organic carbon dispersal throughout the Arctic basin; it also affects albedo and light transmission of the seaice cover.

Campbell and Collin (1958) studied high sediment loads incorporated into sea ice in Foxe Basin, Canada. They concluded that sediment suspended by turbulence is entrained into the ice cover during fall storms. Although they coined the term suspension freezing to describe this process, they gave relatively little insight into the mechanics of the process. Through time, this term has been used to depict the process of incorporating fine-grained sediment into the ice cover (Reimnitz and others, 1992; Nürnberg and others, 1994; Eicken and others 1997; Sherwood, 2000; Dethleff, 2005).

Dethleff (2005) proposed Langmuir circulation (LC) as one possible mechanism for bringing suspended ice and sediment together to drive suspension freezing. It is clear that suspension freezing and turbid ice formation require strong winds and turbulence over a shallow water region where suspended frazil and sediment can interact in the water column, along with subfreezing air temperatures to drive frazil ice formation (Reimnitz and others, 1992). Sherwood (2000) developed a one-dimensional numerical model for suspension freezing that includes currents, mixing, frazil concentration and suspended-sediment concentration. This model can generate reasonable sediment concentrations in turbid ice, although it neglects sediment-ice interactions. Smedsrud (2002) extended this model by incorporating various size classes for sediment and frazil crystals.

Windrows of floating frazil are commonly observed during the initial stages of ice formation in the Arctic (Martin and Kauffman, 1981; Reimnitz and others, 1994; Dethleff, 2005). These streaks, which are aligned roughly in the wind direction, can be spaced from $<2 \mathrm{~m}$ to $>1 \mathrm{~km}$ apart, and can extend for up to $15 \mathrm{~km}$ downwind (maximum values are taken from figure 4 of Drucker and others, 2003). These frazil windrows on the surface indicate active LC (Drucker and others, 2003; Dethleff, 2005).

LC is a type of organized flow characterized by roll vortices of alternating signs oriented with their horizontal axes approximately downwind. The alternating sense of rotation in adjacent vortices leads to formation of a series of alternating convergence and divergence zones at the surface. Buoyant material (such as frazil) accumulates at surface convergence zones and may be transported downward into the water column.

LC is generated by the interaction of Stokes wave drift and vertical vorticity associated with wind-driven currents. Reviews of the states of knowledge of observational, theoretical and computational research in LC research are given in Leibovich (1983), Smith (2001) and Thorpe (2004). It is beyond the scope of this paper to delve into the physics of LC generation; instead we present observations that are applicable to the effect of LC on turbid ice formation.

LC appears to be a ubiquitous feature when wind of more than a few $\mathrm{m} \mathrm{s}^{-1}$ blows across a water surface (Thorpe, 2004). LC cells, defined as the distance between adjacent convergence zones, are usually two to three times the mixed-layer or water depth, so roll vortices are roughly square in cross-section. In ideal cells, downwelling velocities are greater than upwelling velocities, and both vertical and downstream horizontal velocities are greatest at convergence zones, i.e. there is a significant positive correlation between downwind and downward-directed vertical velocities. Weller and others (1985) present one of 


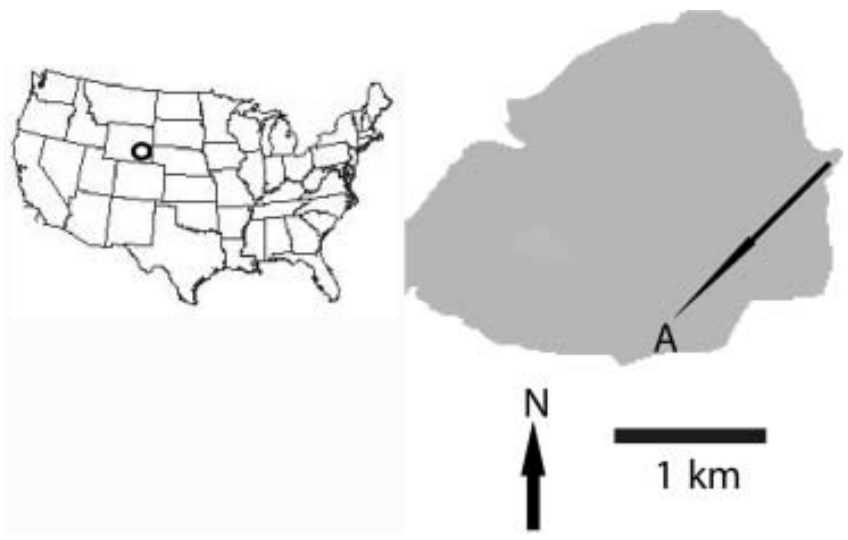

Fig. 1. Left: map of the United States. The position of Lake Hattie, Wyoming, is marked with a ' $O$ '. Right: the east side of Lake Hattie. ' $A$ ' marks the position of the ADV on the south shore of the lake. The arrow marks the wind direction; frazil windrows were aligned roughly parallel to the arrow. The ADV was oriented with the positive $x$ axis pointed into the wind direction.

the few observational datasets of LC velocity measurements made with current meters in the open ocean. They measured vertical, downward-directed LC velocity components of up to $18 \mathrm{~cm} \mathrm{~s}^{-1}$, although the mean velocities were $5-10 \mathrm{~cm} \mathrm{~s}^{-1}$ at the $23 \mathrm{~m}$ sampling depth. Tank studies of LC (Mizuno and Cheng, 1992) show that the basic cross-stream/vertical LC flow characteristics hold, but there is a superimposed circulation consisting of downstream or downwind flow at the water surface and a return flow at the tank bottom.

In an early study, Stommel (1949) calculated particle trajectories for idealized LC roll vortices. He concluded that sinking or rising particles may be trapped in LC vortices. Negatively buoyant particles (sediment in the present context) are trapped under upwelling zones, while positively buoyant particles, i.e. frazil, are trapped at downwelling zones.

Except for tank experiments, there has been relatively little study of LC in shallow water. Gargett and others (2004) present a recent dataset from the New Jersey shelf, USA, where they identified 'Langmuir supercells' that penetrated the entire $15 \mathrm{~m}$ deep water column. They concluded that downward-directed LC jets that penetrate to the seabed are necessary to suspend sediment through the entire water column, and that supercells are a prerequisite for major sediment transport events on the New Jersey shelf. Evidence that LC supercells may form in shallow water in the Beaufort Sea, Alaska, USA, is given by Toimil and Reimnitz (1979), who report on a series of bedforms that may have resulted from LC vortices impinging on the seabed.

It is interesting that conditions for frazil and turbid ice formation (a cold fall storm that mixes the water column to the seabed; Sherwood, 2000) contain a subset of conditions necessary for LC generation (a strong wind blowing across the water surface). It is not clear that LC is a necessary prerequisite for frazil and turbid ice formation, but it seems likely that LC is present during most turbid-ice-forming events. We wondered whether it was possible to see evidence of LC roll vortices in current-meter records recorded during frazil-forming events. In order to study LC roll vortices during suspension freezing events, we made a set of observations in a lake. The LC processes occurring during fall storms are not salinity-dependent, so we argue

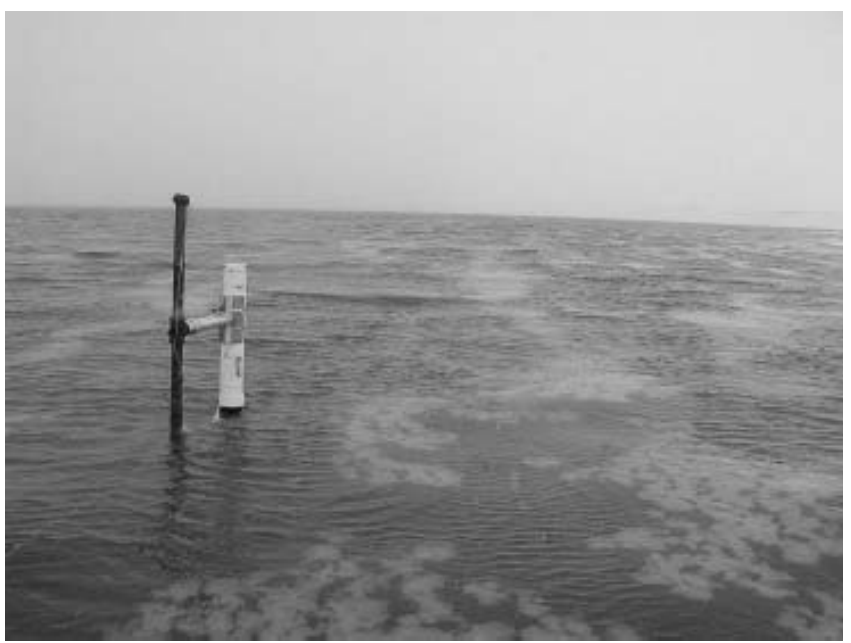

Fig. 2. The surface of Lake Hattie during the experiment. The $\mathrm{ADV}$ is in an upwelling zone between LC convergence zones that are outlined by floating accumulations of slush ice. The two lines of floating ice that bracket the ADV are separated by about $2 \mathrm{~m}$. This view is upwind, looking approximately parallel to the $x$ axis of the ADV.

that the observations made here can be extrapolated to shallow Arctic seas where large volumes of turbid ice form. In this paper, we report on the results of our lake experiments.

\section{METHODS}

The observations for this study were made at Lake Hattie on 28 November 2004. This $9 \mathrm{~km}^{2}$ freshwater lake is located $25 \mathrm{~km}$ west of Laramie, Wyoming, USA, at an elevation of $2200 \mathrm{~m}$ (Fig. 1). The experiment included visual observations of LC windrows on the water surface, measurements of water velocity and temperature, sediment characteristics at the sampling site, and a two-suite collection of sediment in slush ice (ice), interstitial water (IW) and lake water (suspended particulate matter (SPM)) samples.

The experiment was carried out on the morning when the first permanent ice was forming on the lake. The weather during the previous night was cold, with temperatures dropping to $-14^{\circ} \mathrm{C}$, and snow flurries deposited about $5 \mathrm{~cm}$ of snow in and around the lake. Measurements and samples were collected over a $97 \mathrm{~min}$ period beginning at $0936 \mathrm{~h}$. The air temperature during the measurement period remained steady at $-8^{\circ} \mathrm{C}$, with northeast winds that varied between approximately 2 and $5 \mathrm{~m} \mathrm{~s}^{-1}$ (Fig. 1).

There was evidence of active LC over the entire lake surface during the experiment. This evidence consisted of floating windrows of slush ice at LC surface convergence zones (Fig. 2). At the current-meter site, slush ice windrows were $30-50 \mathrm{~cm}$ wide in the cross-wind direction. The spacing between windrows was about $2 \mathrm{~m}$, or roughly twice the water depth. The windrow spacing and widths were measured while standing in the water just downstream of the current-meter site. The windrows tended to be very irregular, with many bifurcations (Fig. 2), and migrated in a cross-wind direction at a rate of $1-4 \mathrm{~cm} \mathrm{~s}^{-1}$. Although there was a slow net offshore (negative) movement of LC cells in the crosswind direction, on occasion the same LC convergence zone would migrate back and forth across the sampling position. Observations from a bluff at the lake shore showed that LC 

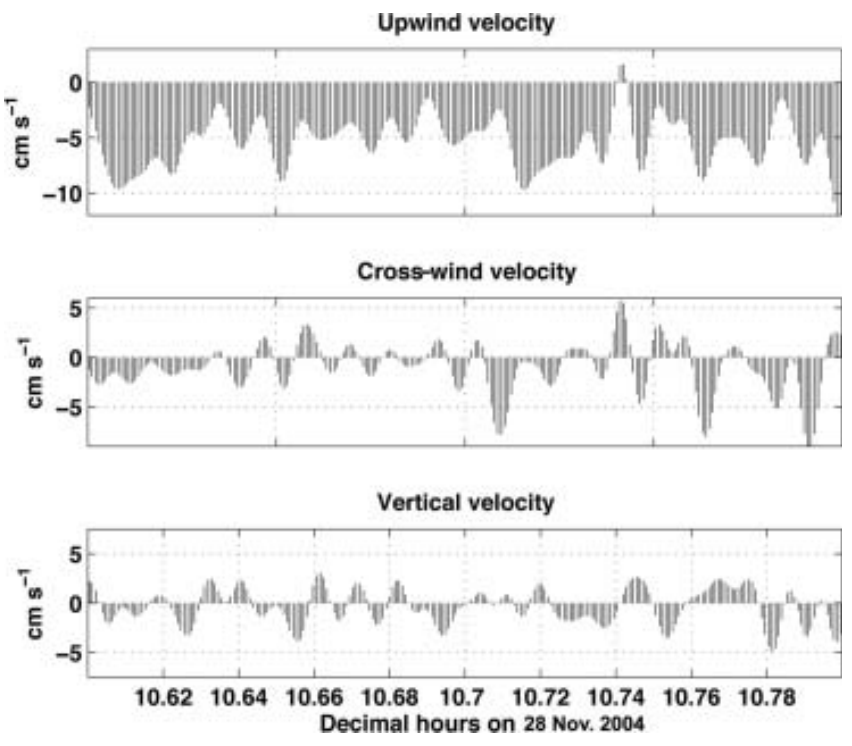

Fig. 3. Filtered time-series data showing the upstream, cross-stream and vertical velocity components measured with the ADV. Downward-directed vertical jets are strong enough to entrain frazil formed at the water surface down into the interior of the flow.

windrows extended upwind all of the way across the lake during the experiment, but we could not determine if windrow spacing was uniform across the lake.

Water velocity, temperature and signal strength were measured with a Sontek Argonaut Acoustic Doppler Velocimeter (ADV). The ADV measures the three components of water velocity in a $0.54 \mathrm{~cm}^{3}$ volume located $10 \mathrm{~cm}$ below the transducer head. A thermistor mounted in the transducer head measured temperature to a stated accuracy of $\pm 0.1^{\circ} \mathrm{C}$ and a precision of $0.03^{\circ} \mathrm{C}$.

During the experiment, the ADV was cantilevered $70 \mathrm{~cm}$ off a $7.5 \mathrm{~cm}$ diameter iron rod that was driven into the lake bed (Fig. 2). The ADV was oriented with its positive $x$ axis directly into the northeast wind. LC windrows were approximately aligned with this wind direction throughout the experiment. The three velocity components are measured in a right-handed, orthogonal coordinate system, with vertical velocity positive up. The ADV was deployed in $90 \mathrm{~cm}$ deep water $20.5 \mathrm{~m}$ from the south shoreline of the lake. The shoreline trends roughly east-west here (Fig. 1), so LC vortices approached the shore at an oblique onshore angle. The water velocity measurements were made $60 \mathrm{~cm}$ above the sandy gravel lake bed. The three components of current velocity, here called upwind, cross-wind and vertical velocities, along with temperature and signal strength, were sampled at $3 \mathrm{~s}$ intervals. Each ADV sample consists of the mean of 30 individual measurements. After the experiment, the raw ADV measurements were corrected for instrument pitch and roll, and the data were filtered with a low-pass filter with a cut-off frequency of $0.042 \mathrm{~Hz}$ to remove velocity fluctuations associated with surface waves.

Wind direction was constant from the northeast during the experiment. Wind speed varied from $<2$ to approximately $5 \mathrm{~m} \mathrm{~s}^{-1}$ during the course of the experiment as snow squalls moved through the area. The fetch was about $1.8 \mathrm{~km}$, and waves responded rapidly to changing wind speeds. Early in the experiment, wave heights were $<5 \mathrm{~cm}$, but during squalls wave heights increased to $15 \mathrm{~cm}$, and white caps formed on the water surface.
Two suites of sediment samples, consisting of SPM, IW and ice, were collected to determine relative sediment concentrations. SPM samples were collected by inverting $1 \mathrm{~L}$ water bottles at mid-depth in the water column between slush ice windrows. These samples represent the sediment concentration in the water column. IW and ice samples were collected by scooping floating frazil from windrows with a strainer. The IW was drained from the slush ice by immediately tapping the strainer on the side of a beaker after the sample was collected, while the ice sample was the material left in the strainer. Processing of the samples is described in Dethleff and Kempema (in press).

\section{RESULTS}

On the morning of our observations, the water surface was covered with slush ice windrows that suggested 'classic' LC. This floating slush ice was semi-consolidated (Fig. 2). The slush ice was advected downwind obliquely towards the lee shore. In the nearly ice-free regions between windrows, we observed individual frazil and/or snow crystals rise to the water surface and move obliquely across the wind direction to accumulate at LC convergence zones, another indication of LC roll vortices. These observations indicate that both frazil formation and LC were occurring throughout the observation period.

The mean, filtered upwind, cross-wind and vertical velocities were $-4.6,-0.5$ and $-0.2 \mathrm{~cm} \mathrm{~s}^{-1}$, respectively. Even though both the cross-wind and vertical velocities have non-zero means, they oscillate regularly across $0 \mathrm{~cm} \mathrm{~s}^{-1}$ (Fig. 3). The negative mean cross-wind velocity indicates a net oblique offshore flow, while the $-0.2 \mathrm{~cm} \mathrm{~s}^{-1}$ mean vertical flow indicates net downwelling at the ADV site.

Correlation coefficients were calculated for the velocity components, ADV signal strength and water temperature. Table 1 shows these correlation coefficients, with the probabilities of these correlation coefficients occurring between random variables ( $p$ values) shown in parentheses. Upwind and cross-wind velocities are significantly correlated. Signal strength is significantly correlated with upwind and vertical velocities, and water temperature is significantly correlated with all other variables.

In the first sample suite, the SPM concentration was $3.07 \mathrm{mg} \mathrm{L}^{-1}$, the IW sediment concentration was $5.39 \mathrm{mg} \mathrm{L}^{-1}$ and the ice had a sediment concentration of $5.56 \mathrm{mg} \mathrm{L}^{-1}$. The second suite of samples, collected later in the experiment when waves were higher and white caps were present on the lake, had concentrations of SPM: $5.26 \mathrm{mg} \mathrm{L}^{-1}$; IW: $7.58 \mathrm{mg} \mathrm{L}^{-1}$; and ice: $5.89 \mathrm{mg} \mathrm{L}^{-1}$. In both suites of samples, sediment concentrations were lowest for the SPM samples, which were collected at mid-water depth (roughly $45 \mathrm{~cm}$ ), while the IW and ice samples were collected within $10 \mathrm{~cm}$ of the water surface (i.e. $80 \mathrm{~cm}$ above the bed). In all of the samples, the majority of the sedimentary particles were in the silt and clay size range, while the local bottom sediment was sandy gravel. A more complete analysis of the sediment characteristics is given in Dethleff and Kempema (in press).

\section{DISCUSSION}

The current-velocity time series (Fig. 3) shows that the current structure we measured in Lake Hattie is not as simple as the ideal Langmuir roll vortices described by 
Table 1. Correlation coefficients and probabilities of significant correlation for parameters measured in the Lake Hattie experiments

\begin{tabular}{lccccc}
\hline & Upstream velocity & Cross-stream velocity & Vertical velocity & Signal strength & Water temperature \\
\hline Upstream velocity & $1(1)$ & $0.42(0)$ & $-0.02(0.51)$ & $-0.37(0)$ & $0.06(0.01)$ \\
Cross-stream velocity & $0.42(0)$ & $1(1)$ & $-0.02(0.34)$ & $0.01(0.78)$ & $0.07(0)$ \\
Vertical velocity & $-0.02(0.51)$ & $-0.02(0.34)$ & $1(1)$ & $-0.08(0)$ & $-0.23(0)$ \\
Signal strength & $-0.37(0)$ & $0.01(0.78)$ & $-0.08(0)$ & $1(1)$ & $-0.08(0)$ \\
Water temperature & $0.06(0.01)$ & $0.07(0)$ & $-0.23(0)$ & $-0.08(0)$ & $1(1)$ \\
\hline
\end{tabular}

Weller and others (1985), Smith (2001) and Thorpe (2004). In idealized LC flow, upwind and vertical velocities should have maximum negative values when the cross-wind velocity decreases through $0 \mathrm{~cm} \mathrm{~s}^{-1}$ and changes direction at surface downwelling zones. We see little evidence of this ideal flow anywhere in the time series. There is a strong positive correlation between upwind and cross-wind velocities, which is attributable to the fact that downwind currents are not aligned with the wind direction (i.e. the ADV $x$ or upwind axis). None of the other velocity components are significantly correlated (Table 1 ). The lack of correlation between upwind and vertical velocities is surprising considering the well-developed, albeit irregular, frazil windrows visible on the water surface during the experiment.

There are a number of possible reasons we do not see the ideal flow, including: (1) The ideal flow is described for open-ocean conditions. The effect of the lake bed on the LC flow structure is not known. (2) We were near the minimum wind speeds necessary to develop LC (Smith, 2001). At higher wind speeds, the current structure may be more developed. (3) The wind was forcing the water in the LC roll vortices obliquely onshore. The measurements were taken only $20.5 \mathrm{~m}$ from the lee shore, and there was an offshore return flow to balance set-up at the shoreline. This offshore return flow is indicated by the mean negative flow in the cross-wind direction and the mean downward-directed flow in the vertical. The net current structure at Lake Hattie was similar to the tank LC flow reported by Mizuno and Cheng (1992), with the LC superimposed on a primary downwind flow at the surface and return flow near the bed. However, the primary flow at Lake Hattie was much more complex than the flow found in a rectangular tank because of the oblique angle between the LC roll vortices and the lee shore.

Even with mean net flows, water motion in the crosswind/vertical plane (approximately perpendicular to the wind direction) indicates LC roll vortices with alternating upwelling and downwelling zones (Fig. 3). Downwelling velocities reached $-8.5 \mathrm{~cm} \mathrm{~s}^{-1}$. For $27 \%$ of the time, vertical velocities were $<-2.5 \mathrm{~cm} \mathrm{~s}^{-1}$, and for $12 \%$ of the time vertical velocities were $<-5 \mathrm{~cm} \mathrm{~s}^{-1}$. Gosink and Osterkamp (1983) measured rise velocities of disk-shaped frazil crystals $1-6 \mathrm{~mm}$ in diameter. For this size range, rise velocities were $<2.5 \mathrm{~cm} \mathrm{~s}^{-1}$. Based on this we conclude that, for a significant portion of the time, and over a significant area of the lake surface, downward-directed currents at Lake Hattie were strong enough to entrain typical frazil crystals down into the water column. This observation is reinforced by our observations of ice crystals continuously rising to the water surface in the regions between frazil windrows. Thus, even with low wind speeds and small waves, LC is effective at entraining frazil into the water column.
Signal strength, a measure of the number of reflectors in a water column, is significantly negatively correlated with upwind velocity, vertical velocity and temperature. The negative correlations with vertical velocity and temperature, along with the significant correlation between vertical velocity and temperature, suggest that the ADV sampled downwelling jets entraining frazil crystals down into the water column. Unfortunately, air bubbles entrained at the water surface are also good reflectors, and it is impossible to determine if bubbles, frazil or, most probably, a combination of the two reflectors are responsible for the increased signal strength associated with downward-directed currents.

If frazil acts like other passive, positively buoyant particles as predicted by Stommel (1949), frazil suspended in the water column will be concentrated under surface convergence zones. Although the ADV was marginally capable of measuring temperature variations on the order of those seen in supercooling, there is a significant correlation between vertical velocity and temperature. During freezing storms, surface water is supercooled as it moves obliquely downwind towards LC convergence zones. This supercooled water is then advected downwards at convergence zones. Frazil trapped under convergence zones will be continuously bathed in this cascade of supercooled water, and will be subject to continuous growth. Frazil in supercooled water is 'sticky' (Carstens, 1966), and will readily stick to sedimentary particles. The sediment found in turbid ice is usually silt- and clay-sized. This size material is most likely to be suspended in the water column during storms. This suggests that the actual entrainment of silt and clay into ice via suspension freezing occurs predominately in the downwelling surface convergence zones of LC cells when frazil is forming. In the Lake Hattie experiments, we found that ice and IW both had higher sediment concentrations than water samples (SPM) collected between slush ice windrows. Based on this we conclude that suspension freezing was occurring during the period our observations were made, and that the newly formed ice had higher sediment concentrations than the water column where the ice formed.

Reimnitz and others (1993) note that the sediment content in seasonal ice formed over the Beaufort Sea shelf varies tremendously each year. This is because freezing and turbulence intensities vary from year to year with differing weather patterns and fetch, and not all conditions for extensive frazil formation, suspension freezing and turbid ice formation are met every year. The conditions that lead to turbid ice formation - freezing fall storms with strong winds blowing across long fetches over shallow continental shelf are also the conditions that lead to larger LC cells with more vigorous circulation. As noted by Gargett and others (2004), Langmuir supercells that penetrate to the seabed are probably an important contributor to the largest sediment 
transport events on the New Jersey continental shelf. It seems probable that similar LC supercells forming over Arctic continental shelves during freezing fall storms are critical components for turbid ice formation and extensive production of sediment-laden ice.

\section{CONCLUSIONS}

In this study, we found that we can identify LC roll vortices during freezing frazil formation events in shallow water with an ADV. These roll vortices are more complex than the idealized LC roll vortices described for open-ocean conditions. The presence of LC roll vortices, combined with increased sediment concentrations in newly formed ice compared to the water column, suggests that LC plays an important role in forming sediment-laden ice in lakes and seas.

We urge that future studies of processes leading to turbid ice formation, whether theoretical or observational, should not ignore the role that LC plays in suspension freezing.

\section{ACKNOWLEDGEMENTS}

We thank E. D'Asaro and an anonymous reviewer for suggestions that improved the manuscript. This work was supported, in part, by the United States Navy, Office of Naval Research (grant No. N00014-02-1-0650).

\section{REFERENCES}

Barnes, P.W., E. Reimnitz and D. Fox. 1982. Ice rafting of finegrained sediment, a sorting and transport mechanism, Beaufort Sea, Alaska. J. Sediment. Petrol., 52(2), 493-502.

Campbell, N.J. and A.E. Collin. 1958. The discoloration of Foxe Basin ice. J. Fish. Res. Board Can., 15, 1175-1188.

Carstens, T. 1966. Experiments with supercooling and ice formation in flowing water. Geofys. Publ., 26(9), 1-18.

Dethleff, D. 2005. Entrainment and export of Laptev Sea ice sediments, Siberian Arctic. J. Geophys. Res., 110(C7), C07009. (10.1029/2004JC002740.)

Dethleff, D. and E.W. Kempema. In press. Langmuir circulation driving sediment entrainment into newly forming ice - tank experiment results with application to nature (Lake Hattie, U.S.A.; Kara Sea, Siberia). J. Geophys. Res.

Dethleff, D. and 6 others. 1998. Winter expedition to the southwestern Kara Sea: investigations on formation and transport of turbid sea-ice. Ber. Polarforsch./Rep. Pol. Res. 271.

Drucker, R., S. Martin and R. Moritz. 2003. Observations of ice thickness and frazil ice in the St. Lawrence Island polynya from satellite imagery, upward looking sonar, and salinity/temperature moorings. J. Geophys. Res., 108(C5), 3149. (10.1029/ 2001JC001213.)

Eicken, H., E. Reimnitz, V. Alexandrov, T. Martin, H. Kassens and T. Viehoff. 1997. Sea-ice processes in the Laptev Sea and their importance for sediment export. Continental Shelf Res., 17(2), 205-233.
Eicken, H. and 6 others. 2005. Sediment transport by sea ice in the Chukchi and Beaufort Seas: increasing importance due to changing ice conditions? Deep-Sea Res. II, 52(24-26), 3281-3302.

Gargett, A., A.E. Wells, A.E. Tejada-Martínez and C.E. Grosch. 2004. Langmuir supercells: a mechanism for sediment resuspension and transport in shallow seas. Science, 306(5703), 1925-1928.

Gosink, J.P. and T.E. Osterkamp. 1983. Measurements and analyses of velocity profiles and frazil ice-crystal rise velocities during periods of frazil-ice formation in rivers. Ann. Glaciol., 4, 79-84.

Kempema, E.W., E. Reimnitz and P.W. Barnes. 1989. Sea ice sediment entrainment and rafting in the Arctic. J. Sediment. Petrol., 59(2), 308-317.

Leibovich, S. 1983. The form and dynamics of Langmuir Circulations. Annu. Rev. Fluid Mech., 15(1), 391-427.

Martin, S. and P. Kauffman. 1981. A field and laboratory study of wave damping by grease ice. J. Glaciol., 27(96), 283-313.

Mizuno, S. and Z. Cheng. 1992. A pair of Langmuir cells in a laboratory tank (I) wind-only experiment. J. Oceanogr., 48(1), 37-57.

Nürnberg, D. and 7 others. 1994. Sediment in Arctic sea ice: implications for entrainment, transport and release. Mar. Geol., 119(3-4), 185-214.

Osterkamp, T.E. and J.P. Gosink. 1984. Observations and analysis of sediment-laden sea ice. In Barnes, P.W., D.M. Scholl and E. Reimnitz, eds. The Alaskan Beaufort Sea: ecosystems and environments. Orlando, FL, Academic Press, 73-94.

Reimnitz, E. and E.W. Kempema. 1988. Correspondence. Ice rafting: an indication of glaciation? J. Glaciol., 34(117), 254-255.

Reimnitz, E., L. Marincovich, Jr, M. McCormick and W.M. Briggs. 1992. Suspension freezing of bottom sediment and biota in the Northwest Passage and implications for Arctic Ocean sedimentation. Can. J. Earth Sci., 29(4), 693-703.

Reimnitz, E., M. McCormick, K. McDougall and E. Brouwers. 1993. Sediment export by ice rafting from a coastal polynya, Arctic Alaska, U.S.A. Arct. Alp. Res., 25(2), 83-98.

Reimnitz, E., D. Dethleff and D. Nürnberg. 1994. Contrasts in Arctic shelf sea-ice regimes and some implications: Beaufort Sea versus Laptev Sea. Mar. Geol., 119(3-4), 215-225.

Sherwood, C.R. 2000. Numerical model of frazil-ice and suspendedsediment concentrations, and formation of sediment-laden ice in the Kara Sea. J. Geophys. Res., 105(C6), 14,061-14,080.

Smedsrud, L.H. 2002. A model for entrainment of sediment into sea ice by aggregation between frazil-ice crystals and sediment grains. J. Glaciol., 48(160), 51-61.

Smith, J.A. 2001. Observations and theories of Langmuir circulation: a story of mixing. In Lumley, J.L., ed. Fluid mechanics and the environment: dynamical approaches. New York, Springer, 295-314. (Lecture Notes in Physics 566.)

Stommel, H. 1949. Trajectories of small bodies sinking slowly through convection cells. J. Mar. Res., 8, 24-29.

Thorpe, S.A. 2004. Langmuir circulation. Annu. Rev. Fluid Mech., 36, 55-79.

Toimil, L.J. and E. Reimnitz. 1979. A herringbone bedform pattern of possible Taylor-Görtler type flow origin seen in sonographs. Sediment. Geol., 22, 219-228.

Weller, R.A., J.P. Dean, J.F. Price, E.A. Francis, J. Marra and D.C. Boardman. 1985. Three-dimensional flow in the upper ocean. Science, 227(4694), 1552-1556. 